\title{
EXPERIMENTAL STUDY ON HPLC DETERMINATION OF ASTRAGALOSIDE IN QISHEN HUOXUE GRANULE AND ITS PROTECTIVE EFFECT IN SEPTIC RATS
}

\author{
USO DE MÉTODO DE HPLC PARA DETERMINAÇÃO DO TEOR DE \\ ASTRAGALOSIDE NO GRANULE DE ASTRAGALUS E O ESTUDO DE SUA \\ FUNÇÃO PARA TRATAMENTO DE SEPSE NO CORPO DE RATO
}

\author{
Xiaoqi SUN ${ }^{1}$; Hong ZHANG ${ }^{1}$; Wenhua $\mathrm{ZOU}^{1}$; Ying CHEN ${ }^{2 *}$ \\ 1. Changchun Medical College, Changchun City of Jilin Province, China; 2. ICU of The First Hospital of Jilin University, Changchun \\ City of Jilin Province, China.
}

\begin{abstract}
This study was undertaken to determine the astragaloside content in Qishen Huoxue Granule (QHG) by HPLC and to investigate the protective effect of astragaloside in septic rats. Methods: Dikma Diamonsil ${ }^{\mathrm{TM}} \mathrm{C}_{18}$ column was used. Mobile phase was methanol: acetonitrile (42:58) and detection was performed at $205 \mathrm{~nm}$. Healthy rats were randomly divided into three groups, group A: sham operation (SO) group; group B: cecal ligation and puncture (CLP) group; and group C: CLP QHG treatment group. $72 \mathrm{~h}$ after model establishment, plasma tumor necrosis factor- $\alpha$ $(\mathrm{TNF}-\alpha)$, plasma and peritoneal albumin concentrations, as well as mesenteric venular flow velocity in each group were measured and degree of intestinal mucosal injury was observed. Average recovery was $100.7 \%$, with a RSD of $2.20 \%$. Sample concentration exhibited good linearity with peak area within a $0.01 \sim 0.2 \mathrm{mg} / \mathrm{mL}$ range. After CLP, plasma TNF- $\alpha$ concentration and albumin leakage in rats increased markedly; such increases were more significant in group B than group $\mathrm{C}(\mathrm{P}<0.01)$. Changes in intestinal mucosal scores also presented the same trend $(\mathrm{P}<0.01)$. Mesenteric venular flow slowed down and plasma albumin concentration lowered; such decreases were more significant in group $\mathrm{B}$ than group $\mathrm{C}(\mathrm{P}<0.05)$. QHG can reduce the inflammatory response and intestinal mucosal injury in rats with CLP-induced sepsis.
\end{abstract}

KEYWORDS: Qishen Huoxue Granule. HPLC. Astragaloside. Sepsis.

\section{INTRODUCTION}

Sepsis is a systemic inflammatory response syndrome (SIRS) caused by infectious factors. Its global incidence is up to 1.8 million cases per year; and mortality of severe sepsis approaches 30\% (ANGUS et al., 2001; WATANABE et al., 2007). Clinical features of sepsis are systemic high metabolic state, hyperdynamic circulatory state and excessive inflammatory response secondary to various severe infections; severe sepsis is complicated by one or more organ dysfunctions and accompanies varying degrees of coagulation disorders (WEYCKER et al., 2003; NICOLAI et al., 2015). Meanwhile, part of coagulation factors produced during coagulation process can contribute to the extension of inflammatory response; the two complement each other, leading to deterioration of the condition. From the perspective of traditional Chinese medicine, this study establishes a rat model of sepsis by CLP; determines and compares indices such as plasma TNF- $\alpha$ concentration, peritoneal albumin leakage, mesenteric venular flow velocity and intestinal mucosal injury score; observes the protective effect of QHG in septic rats; and explores its mechanisms of action.
QHG is a common traditional Chinese drug with qi-invigorating, superficies-consolidating, dieresis-inducing and toxin-expelling functions, which is mainly used in the treatment of nonspecific immune dysfunction, hepatitis B and cardiovascular diseases. As one constituent of QHG, astragaloside has multiple functions such as lowering blood pressure, suppressing inflammation, stabilizing erythrocyte membrane, increasing plasma cAMP level, promoting DNA synthesis in regenerating liver of mice and enhancing immune function (Danai et al., 2005; He et al., 2014). Therefore, we studied the method for quantitative determination of astragaloside, one constituent of QHG, in order to better control QHG quality and provide basis for future development of its quality standards. In this study, astragaloside content is determined by HPLC and its sample concentration is found linear with peak area within a $0.01 \sim 0.2$ $\mathrm{mg} / \mathrm{mL}$ range. The method proposed is highly sensitive and reproducible, which can accurately determine astragaloside content in QHG. Thus we aimed to determine the astragaloside content in Qishen Huoxue Granule (QHG) by HPLC and to investigate the protective effect of astragaloside in septic rats. Methods: Dikma Diamonsil ${ }^{\mathrm{TM}} \mathrm{C}_{18}$ column was used. Mobile phase was methanol: acetonitrile (42:58) and detection was performed at $205 \mathrm{~nm}$. 


\section{MATERIAL AND METHODS}

We used SHIMADZU LC-10A HPLC System, Japan (DGU-4A degasser, CBM-10A communications bus module, LC-10AD pump, SPD-M10A diode array detector, SIL-10A autosampler, CTO-10A column oven and ClassLc10 workstation).

Astragaloside was purchased from the National Institute for the Control of Pharmaceutical and Biological Products, and its batch number was 201402147B.

QHG was purchased from Guangzhou Baiyuntang Pharmaceutical Factory, and its batch number was 20140901.

We used the following reagents: acetonitrile, methanol (HPLC grade, Merck, Germany); n-butanol, ethyl ether (analytical grade, Nanjing Qitian Reagent Company); water, redistilled water, deionized water (prepared with a water deionizer).

\section{Chromatographic conditions}

Table 1. Concentration and peak area of standard sample

\begin{tabular}{cc}
\hline $\mathrm{C}(\mathrm{mg} / \mathrm{ml})$ & Peak area $(\mathrm{A})$ \\
\hline 0.1 & 0.4711 \\
0.3 & 0.5041 \\
0.5 & 0.5452 \\
1.0 & 0.634 \\
2.0 & 0.8199 \\
\hline
\end{tabular}

\section{Accuracy test}

$4.50 \mathrm{mg}$ of astragaloside reference substance was accurately weighed, dissolved in methanol and diluted to the mark in a $10 \mathrm{~mL}$ volumetric flask. $20 \mu \mathrm{L}$ of the solution was accurately aspirated and injected five consecutive times to measure peak area, whose RSD was found to be $2.23 \%$.
Column: Dikma Diamonsil ${ }^{\mathrm{TM}} \mathrm{C}_{18}$ column $(250 \times 4.6 \mathrm{~mm} \times 10 \mu \mathrm{m})$, Nanjing Microtech Scientific Instruments Co., Ltd.; mobile phase: methanol: acetonitrile (42:58); flow rate: 1.0 $\mathrm{ml} / \mathrm{min}$; detection wavelength: $205 \mathrm{~nm}$.

\section{Plotting of standard curve}

$5.00 \mathrm{mg}$ of astragaloside reference substance was accurately weighed, placed in a 25 $\mathrm{mL}$ volumetric flask, dissolved in HPLC grade methanol and diluted to the mark. 0.5, 1.5, 2.5, 5 and $10 \mathrm{~mL}$ of the solution were accurately aspirated, respectively, diluted to the mark with methanol in $10 \mathrm{~mL}$ volumetric flasks and filtered through 0.45 $\mu \mathrm{L}$ microporous membrane. Next, $20 \mu \mathrm{L}$ of the solutions were injected for determination according to the above chromatographic conditions. A unique absorption peak appeared around $t_{R}=10.56 \mathrm{~min}$. Regression curve was plotted with peak area as ordinate and sample concentration as abscissa. Regression equation was $\mathrm{A}=0.184 \mathrm{C}+0.4513$, $\mathrm{R}^{2}=0.9998$ and linearity range was $0.01 \sim 0.20$ $\mathrm{mg} / \mathrm{mL}$, as shown in Table 1 .

\section{Recovery test}

$5 \mathrm{~g}$ of QHG sample with known astragaloside content was divided into 10 aliquots. 5 aliquots of the sample were accurately added with $0.2 \mathrm{~mL}$ of $2.0 \mathrm{mg} / \mathrm{mL}$ astragaloside reference solution, respectively, and operated as per the method under "Sample determination". The results are shown in Table 2. Average recovery was $100.7 \%$, with a RSD of $2.20 \%$.

Table 2. Results of recovery

\begin{tabular}{cccc}
\hline $\begin{array}{c}\text { Content of astragaloside } \\
\text { in sample }(\mathrm{mg})\end{array}$ & $\begin{array}{c}\text { Adding weight } \\
\text { of astragaloside }(\mathrm{mg})\end{array}$ & $\begin{array}{c}\text { Measurement } \\
\text { weight }(\mathrm{mg})\end{array}$ & Recovery $(\%)$ \\
\hline 0.421 & 0.400 & 0.832 & 102.75 \\
0.412 & 0.400 & 0.815 & 100.75 \\
0.396 & 0.400 & 0.804 & 102.00 \\
0.402 & 0.400 & 0.790 & 97.00 \\
0.397 & 0.400 & 0.801 & 101.00 \\
\hline
\end{tabular}




\section{Stability test}

Sample solution was kept at room temperature and determined at $0,3,6,12$ and $24 \mathrm{~h}$ for a total of five times. The contents were 0.823 , $0.817,0.792,0.801$ and $0.805 \mathrm{mg} / \mathrm{g}$, respectively, with a RSD of $1.54 \%$, demonstrating stable astragaloside content in the determined QHG within $24 \mathrm{~h}$ (kept out of the sunshine).

\section{Sample determination}

$50 \mathrm{~g}$ of QHG was extracted by adding 50 $\mathrm{mL}$ of water and concentrated to $30 \mathrm{~mL}$ by heating. The supernatant was added with substantial amount of methanol, shaken and suction filtered. Then, methanol was removed to dryness from the filtrate with a rotary vacuum film evaporator, and the residue was prepared into an aqueous solution by adding small amount of $\mathrm{H}_{2} \mathrm{O}$, and shaken out and degreased three times with $100 \mathrm{~mL}$ of ethyl ether.
Next, supernatant was extracted several times with water-saturated n-butanol, then n-butanol solutions were combined, n-butanol was rotary evaporated to dryness under reduced pressure, and diluted to 50 $\mathrm{mL}$ with methanol. Afterwards, $1 \mathrm{~mL}$ of the solution was precisely drawn into a $50 \mathrm{~mL}$ volumetric flask, diluted to the mark with HPLC grade methanol, shaken out and passed through microporous membrane. Finally, $20 \mu \mathrm{L}$ of the filtrate was injected for determination as per the above chromatographic conditions, content was calculated according to the recovery equation, and chromatograms were obtained (Figures 1, 2). Chromatogram of the sample is shown in Figure 1, while the chromatogram of control is shown in Figure 2. The results are shown in Table $3.50 \mathrm{~g}$ of QHG contained $40.02 \mathrm{mg}$ of astragaloside, which was equivalent to $0.8000 \mathrm{mg}$ of astragaloside in per gram of QHG.

Tabela 3: Measurement results of the sample content

\begin{tabular}{ccccccc}
\hline $\mathrm{n}$ & 1 & 2 & 3 & 4 & 5 & Mean \\
\hline $\mathrm{C}(\mathrm{mg} / \mathrm{g})$ & 0.8023 & 0.8012 & 0.8104 & 0.7927 & 0.8108 & 0.8035 \\
\hline
\end{tabular}

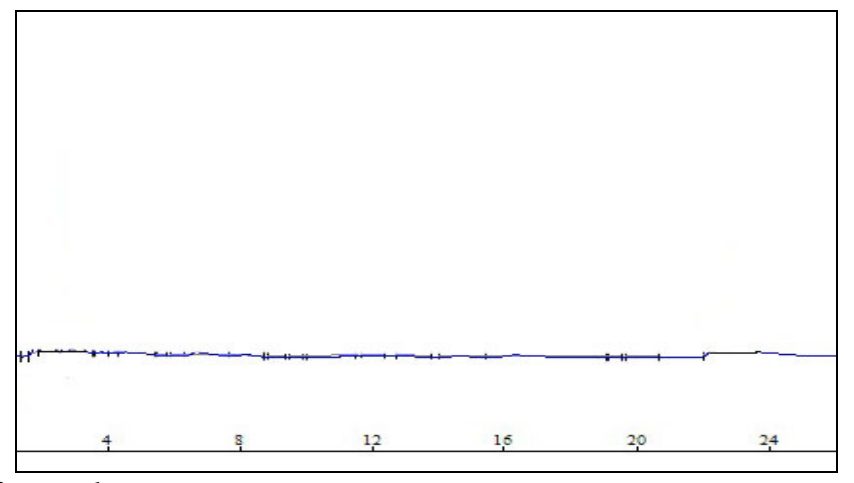

Figure 1: Chromatogram of sample

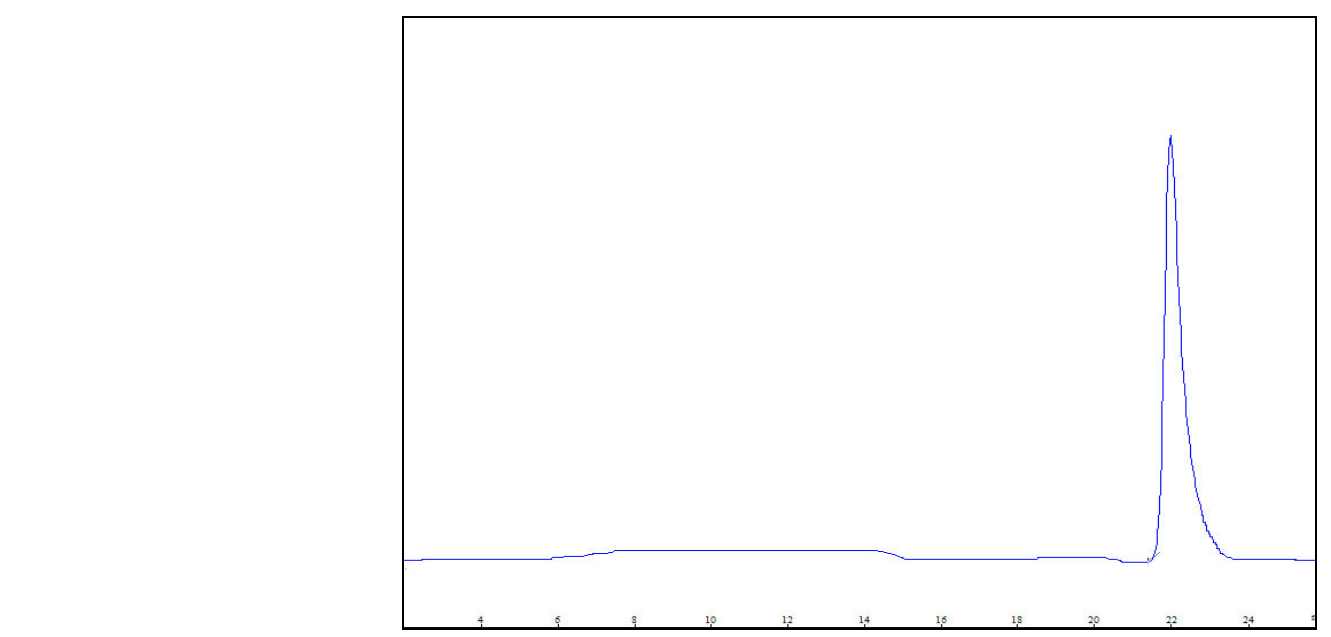

Figure 2: Chromatogram of control 


\section{Model preparation}

30 healthy male SD rats, each weighing 180-230 g (provided by the Laboratory Animal Center of Sichuan Medical University), were randomly divided into group A (SO group), group B (CLP group) and group C (CLP QHG treatment group), $n=10$ in each group. After anesthesia by intraperitoneal injection of $45 \mathrm{mg} / \mathrm{kg} \quad 3 \%$ pentobarbital sodium solution, lower abdomen was incised $2 \mathrm{~cm}$ along the midline to expose the cecum. In group $\mathrm{A}$, abdomen was closed after turning cecum; while in groups B and C, one third of cecum was ligated with silk suture (avoid intestinal obstruction), needle puncture was performed, and intestinal contents were extruded to cause abdominal infection, then abdomen was closed after cecal return. After model creation, rats in group $\mathrm{C}$ were intragastrically administered $60 \mathrm{mg} / \mathrm{kg}$ suspension of QHG extract (self-prepared) twice daily, while group B was administered equivalent normal saline. Mental state, activities, eating and other status of rats in each group were observed during the experiment.

\section{Specimen processing and testing methods}

$72 \mathrm{~h}$ after model creation, rats were anesthetized by intraperitoneal injection of $3 \%$ pentobarbital sodium solution, and their intraperitoneal infection status was observed. Abdominal cavity was washed with $6 \mathrm{ml}$ of normal saline; then the wash fluid was collected and centrifuged at $3000 \mathrm{rpm} / \mathrm{min}$ for $15 \mathrm{~min}$ to collect the supernatant. $1 \mathrm{ml}$ of FITC-stained erythrocytes was injected through internal jugular vein of rats. Venules with small intestinal mesenteric diameter of $20 \sim 30 \mathrm{~nm}$ were selected to collect and record venular flow velocity using BX50 fluorescence microscope and Med Lab biological signal acquisition and processing system. The animals were killed after sampling vena cava bloods and approximately $1 \mathrm{~cm}$ of jejunum segments was removed. After being allowed to stand for $30 \mathrm{~min}$, the bloods were centrifuged at $3000 \mathrm{rpm} / \mathrm{min}$ for 10 min; then plasmas were collected and stored at $70^{\circ} \mathrm{C}$. The jejunum tissues were fixed in $10 \%$ formalin fixative. Albumin levels in plasma and peritoneal exudate were automatically analyzed and determined by bromocresol purple (BCP) method, and plasma TNF- $\alpha$ level was determined by radioimmunoassay. The fixed jejunum specimens were embedded in paraffin, stained with $\mathrm{HE}$, and then observed under ordinary optical microscope, followed by pathological scoring of intestinal mucosal injury (Chu et al., 1970; Haj et al., 2014). Grade 0: normal mucosal villi; Grade 1: subepithelial space enlargement, vascular congestion; Grade 2: apparent subepithelial space enlargement, separation of epithelium from lamina propria; Grade 3: mucous epithelial desquamation, partial villous tip exfoliation; Grade 4: villous exfoliation, exposure of lamina propria and dilated blood vessels; Grade 5: lamina propria decomposition, hemorrhage, ulcers.

\section{Statistical processing}

SPSS 10.0 statistical software was used. Numeric variables were expressed as $(\mathrm{x} \pm \mathrm{s})$, and analyzed by Student-Newman-Keuls test, whereas Kruskal Wallis test was utilized for categorical variables.

\section{RESULTS}

During the experiment, all of 30 rats survived. Rats in group A had good mental state, normal activity and good appetite. After surgery, most rats in groups B and C showed low spirits, reduced activity and decreased appetite in a gradual worsening trend. All experimental procedures were approved by the Animal Research Ethics Committee. After the animals were killed, normal intraperitoneal cavity or small amount of intraperitoneal adhesions were seen in group A. Bloody or purulent exudate with offensive odor was noted in the peritoneal cavities in groups B and C, as well as intestinal bloating, visceral hyperemia, edema and loss of original luster. Abdominal infection between the two groups showed no significant difference.

Comparison of TNF- $\alpha$, mesenteric venular flow velocity, peritoneal albumin, plasma albumin and albumin leakage among three groups. After CLP, plasma TNF-aconcentration and albumin leakage increased markedly, such increases were more significant in group $\mathrm{B}$ than group $\mathrm{C}(\mathrm{P}<0.01)$. After CLP, mesenteric venular flow slowed down and plasma albumin concentration lowered; such decreases were more significant in group $B$ than group $\mathrm{C}(\mathrm{P}<0.05)$, see Table 4.

Group A presented normal intestinal mucosa or mild mucosal edema, hyperemia (Grade $0-1$ ). Intestinal villous exfoliation, exposure of lamina propria and dilated blood vessels were seen in group B (Grade 4). In group C, intestinal epithelia were separated from lamina propria and partial epithelial desquamation was observed (Grade 3). Differences among three groups were statistically significant $(\mathrm{P}<0.01)$, besides, significant differences were also present between groups $\mathrm{B}$ and $\mathrm{C}(\mathrm{P}<0.01)$. 
Table 4: Comparison of TNF- $\alpha$, mesenteric venular flow velocity, peritoneal albumin, plasma albumin and albumin leakage among three groups

\begin{tabular}{ccccccc}
\hline Group & $\begin{array}{c}\text { Number } \\
\text { of cases }\end{array}$ & $\begin{array}{c}\text { TNF- } \alpha \\
(\mathrm{ng} / \mathrm{ml})\end{array}$ & $\begin{array}{c}\text { Mesenteric venular } \\
\text { flow velocity } \\
(\mathrm{mm} / \mathrm{s})\end{array}$ & $\begin{array}{c}\text { Peritoneal } \\
\text { albumin }(\mathrm{g} / \mathrm{L})\end{array}$ & $\begin{array}{c}\text { Plasma } \\
\text { albumin }(\mathrm{g} / \mathrm{L})\end{array}$ & $\begin{array}{c}\text { Albumin } \\
\text { leakage }(\%)\end{array}$ \\
\hline $\begin{array}{c}\text { Group } \\
\text { A }\end{array}$ & 10 & $1.41 \pm 0.51$ & $0.81 \pm 0.10$ & $2.89 \pm 0.56$ & $27.23 \pm 4.55$ & $0.11 \pm 0.01$ \\
$\begin{array}{c}\text { Group } \\
\text { B }\end{array}$ & 10 & $6.23 \pm 1.72^{* *}$ & $0.50 \pm 0.09^{* *}$ & $4.20 \pm 1.07^{*}$ & $12.23 \pm 5.08^{* *}$ & $0.38 \pm 0.01^{* *}$ \\
$\begin{array}{l}\text { Group } \\
\text { C }\end{array}$ & 10 & $3.66 \pm 1.02^{* * \# \#}$ & $0.64 \pm 0.15^{* \#}$ & $3.54 \pm 0.55$ & $19.32 \pm 2.89^{* * \#}$ & $0.18 \pm 0.02^{* \# \#}$ \\
\hline
\end{tabular}

Note: Comparison with group $\mathrm{A},{ }^{*} \mathrm{P}<0.05 ;{ }^{* *} \mathrm{P}<0.01$, comparison with group $\mathrm{B},{ }^{\#} \mathrm{P}<0.05 ;{ }^{\# \#} \mathrm{P}<0.01$

\section{DISCUSSION}

This study investigated the preparation process of QHG methanol extract where polysaccharides and proteins were removed from QHG aqueous extract by methanol precipitation. The results show that this method has the advantages of complete extraction, small loss and good separation. Researchers (KWON et al., 2012) have determined astragaloside content using acetonitrile-water as the mobile phase. We found during the experiment that negative peak appeared under such mobile phase, which had poor peak shapes and were affected largely by the mobile phase, making it difficult to grasp the retention time. We also investigated the experimental results where different proportions of methanol: water were used as the mobile phase and found that optimal efficiency could be achieved when methanol: acetonitrile (42:58) were selected as the mobile phase. Given the rather abundant types and similar structures of astragalosides with end absorption only at $200 \mathrm{~nm}$ upon UV scanning, detection was done at $200 \mathrm{~nm}$. Our experiment showed that the longer the wavelength, the smaller the noise, but the lower the sensitivity; and the closer to $200 \mathrm{~nm}$, the higher the sensitivity, but the greater the noise. After comprehensive investigation of these two factors, $205 \mathrm{~nm}$ was selected as the determination wavelength in this experiment. Astragaloside content in QHG is very low, which is mainly subjected to factors like geographical origin, growing time and harvesting season of major herb (Stragalus Membranaceus (Fisch.) Bunge.). The specific differences need further study.

In the research of sepsis, animal model of sepsis is usually established by lethal injection of $\mathrm{E}$. coli, injection of lipopolysaccharide (LPS), CLP and so on. Among them, CLP method is believed to be able to better reflect the clinical and pathological processes (HADJIMINAS et al., 1994). In this study, rats begin to manifest malaise, restlessness, piloerection, diarrhea and other symptoms after CLP. After being killed, bloody or purulent exudate with offensive odor is found in the peritoneal cavities, as well as intestinal bloating and visceral congestive edema. After surgery, blood proinflammatory cytokine $\mathrm{TNF}-\alpha$ in rats rises significantly compared with before surgery, which is consistent with the literature results (BAKER et al., 1983), indicating the successful replication of rat sepsis model.

Main physiological functions of albumin are maintenance of plasma colloid osmotic pressure and transport of various substances in the blood. Severe infections and sepsis caused by them are often accompanied by hypoproteinemia and are closely related to prognosis (ARIF et al., 2002). It is currently believed that the albumin shift from blood to other extravascular tissues led by increased vascular permeability is an important cause of sharp decline in albumin level (VANDOORNE et al., 2010). In case of peritoneal inflammation after CLP due to bacterial infections, peritoneum is congested and edematous; capillary wall permeability increases; and substantial amount of albumin directly reaches the damaged tissues through more permeable capillaries to be involved in metabolism (SCHWENK et al., 1998). Measurement of transperitoneal albumin transport status with the ratio of peritoneal exudate albumin to plasma albumin is a common method of transperitoneal albumin loss estimation. This experimental study shows that after CLP, albumin pours into the peritoneal cavity and plasma albumin concentration lowers. QHG has some restricting effect on such albumin loss.

The role of intestinal tract in the pathological process of sepsis is gaining increasing attention. Under normal conditions, intestinal mucosae have a strong barrier action on intestinal bacteria and toxins. But when the intestinal mucosal 
barrier is damaged, intestinal vascular permeability increases; mucous epithelia swell; epithelial cells and intercellular junctions fracture; cell necrosis or apoptosis occurs to form ulcers, resulting in increased intestinal permeability, and thereby causes intestinal bacterial translocation and enterogenous infections. Mechanisms contributing to the intestinal barrier dysfunction are complex, which are mainly: 1) intestinal microcirculation disturbance, accumulation of acidic metabolites. Decreased PH value of intestinal mucosa is consistent with increased intestinal permeability (SCHWENK et al., 1995; Benjamin et al., 2015). The accumulation of acidic metabolites lead to local acidosis, which can directly cause cellular metabolic disturbance and tissue damage, and can also exacerbate cell and tissue edemas and increase epithelial permeability through increased inflow of extracellular calcium ions. 2) The roles of cytokines and inflammatory mediators. Some studies have shown that TNF- $\alpha$, IL-1, IL-6 and IL-4 cause intestinal mucosal damage by disrupting tight junctions between cells. The results of this study indicate that QHG can inhibit the elevation of plasma TNF- $\alpha$ after CLP; slow down the decline of mesenteric venular flow velocity in rats; improve intestinal microcirculation; and reduce the degree of inflammatory intestinal injury. This shows the inhibitory effect of QHG on inflammatory response in rats with CLP-induced sepsis. QHG can reduce the inflammatory response and intestinal mucosal injury in rats with CLP-induced sepsis.

RESUMO: determinar o teor de astragaloside no granule de astragalus, estudar a função de protecção da emodina para tratamento de sepse no corpo de rato. Método: utiliza-se Dikma DiamonsilTM C18, A fase móvel é metanol - acetonitrilo, e é detectado em 205nm; os ratos saudáveis são divididos aleatoriamente em três grupos, grupo A: grupo fingido; grupo B: grupo de ligadura e perfuração cecal(CLP): grupo C: CLP grupo com tratamento de granule de astragalus. Construi-se um modelo, 72 horas depois, observam-se separadamente em cada plasma o factor de necrose tumoral $-\alpha(\mathrm{TNF}-\alpha)$, a concentração de albumina peritoneal na intraperitoneal e plasma, velocidade do fluxo venoso de mesentério e observa a extensão do dano para intestino. Resultados: A taxa de recuperação média é de 100,7\%, DPR de 2,20\%, a concentração da amostra está entre 0,01 0,2 mg / $\mathrm{mL}$ e mante uma boa relação linear com a área do pico. Depois de execução de CLP, aumentam-se obviamente a concentração de TNF- $\alpha$ em plasma de rato e a taxa de perda de albumina, e o aumento de grupo B é mais significativo do que grupo $\mathrm{C}(\mathrm{P}<0,01)$, e as alterações na pontuação das lesões intestinais têm a mesma tendência $(\mathrm{P}<0,01)$; diminui-se a velocidade do fluxo venoso de mesentério, e também reduz-se a concentração de albumina peritoneal em plasma, e a diminuição do grupo B é mais óbvia do que a do grupo $\mathrm{C}(\mathrm{P}<0.05)$. Conclusão: granule de astragalus consegue aliviar a infeção do rato com sepse causada por CLP e diminuir as lesões intestinais.

PALAVRAS-CHAVE: Granule de astragalus. HPLC. Astragaloside. Sepse.

\section{REFERENCES}

Angus, D. C.; Linde-Zwirble, W. T.; Lidicker, J. M. A.; Clermont, G.; Carcillo, J.; Pinsky, M. R. Epidemiology of severe sepsis in the United States: Analysis of incidence, outcome, and associated costs of care. Crit CareMed, v. 29, p. 1303 1310, 2001. http://dx.doi.org/10.1097/00003246-200107000-00002

Arif, S. K.; Verheij, J.; Groeneveld, A. B.; Raijmakers, P. G. Hypoproteinemia as a marker of acute respiratory distress syndrome in critically ill patients with pulmonary edema. Intensive care medicine, v. 28, n. 3, p. 310317, 2002. http://dx.doi.org/10.1007/s00134-002-1220-y

Baker, C. C.; Chaudry, I. H.; Gaines, H. O. Evaluation of factors affecting mortalityrate after sepsis in a murine cecal ligation and puncture model. Surgery, v. 94, p. 331-338, 1983.

Benjamin, W.; Danny, R.; Joachim, B.; Jan, T.; Pieter, A.; Patrick, A. Evaluation of fasted and fed state simulated and human intestinal fluids as solvent system in the Ussing chambers model to explore food effects on intestinal permeability. International Journal of Pharmaceutics, v. 478, n. 2, p. 736-744, 2015. http://dx.doi.org/10.1016/j.ijpharm.2014.12.021

Chu, J. C.; Alice, H. M.; Rea, B. Intestinalmucosal lesion in low-flowStates. Exp Sur; v. 101, n. 10, p. 478483, 1970. 
Danai, P.; Matin, G. S. Epidemiology of sepsis : recent advances. Curt Infect Dis Rep, v. 7, p. 329-334, 2005. http://dx.doi.org/10.1007/s11908-005-0005-1

Hadjiminas, D.J.; McMasters, K.M.; Peyton, J.C.; William, G.C.; Tissue tumor necrosis factor mRNA expression following cecalligation and puncture or intraperintoneal injection of endstzxin. J Surg Res, v. 56, n. 6, p. 549-555, 1994. http://dx.doi.org/10.1006/jsre.1994.1088

Haj, B.; Sukhotnik, I.; Shaoul, R.; Pollak, Y.; Coran, A. G.; Bitterman, A.; Matter, I. Effect of ozone on intestinal recovery following intestinal ischemia-reperfusion injury in a rat. Pediatr Surg Int, v. 30, n. 2, p. 181-188, 2014. http://dx.doi.org/10.1007/s00383-013-3448-8

He, Y. X.; Du, M.; Shi, H. L.; Huang, F.; Liu, H. S.; Wu, H.; Zhang, B. B.; Dou, W.; Wu, X. J.; Wang, Z. T. Astragalosides from Radix Astragali benefits experimental autoimmune encephalomyelitis in C57BL/6 mice at multiple levels. BMC Complement Altern Med, v. 14, n. 1, p. 313-315, 2014. http://dx.doi.org/10.1186/14726882-14-313

Kwon, H. J.; Park, Y. D. Determination of astragalin and astragaloside content in Radix Astragali using highperformance liquid chromatography coupled with pulsed amperometric detection. Journal of Chromatography A, v. 1232, p. 212-217, 2012. http://dx.doi.org/10.1016/j.chroma.2011.12.035

Nicolai, H.; Sisse, R. O.; Jørn, W.; Theis, L.; Morten, H. M.; Hamid, T.; Morten, S.; Frank, P.; Peter, S. J.; Jonas, N.; Peter, B. H.; Pär, I. J.; Anders P. Thromboelastography in patients with severe sepsis: a prospective cohort study. Intensive Care Medicine, v. 41, n. 1, p. 77-85, 2015. http://dx.doi.org/10.1007/s00134-014$3552-9$

Schwenk, A.; Ward, L. C.; Elia, M.; Scott, G. M. Bioelectrical impedance analysis predicts outcome inpatientswithsuspectedbacteremia. Infection, v. 26, n. 5, p. 277-282, 1998.

http://dx.doi.org/10.1007/BF02962247

Vandoorne, K.; Addadi, Y.; Neeman, M. Visualizing vascular permeability and lymphatic drainage using labeled serum albumin. Angiogenesis, v. 13, n. 2, p. 75-85, 2010. http://dx.doi.org/10.1007/s10456-010-9170-4

Wang, X. D.; Deng, X. M.; Haraldsen, P. Anti-oxidant and calcium channel blockers counteract endothelial barrier injury induced by acute pancreatitis in rats. Scand J Gastroenterol, v. 30, p. 1129-1136, 1995. http://dx.doi.org/10.3109/00365529509101619

WATANABE, M.; NAITO, T.; NIHEI, K.; SUZUKI, S.; MISHINA, T.; UCHIGASAKI, S.; FUKASE, M. A Patient with gastrointestinal stromal tumor of the stomach with multiple hepatic metastases who died of septicemia following abscess formation after administration of imatinib mesylate. Journal of Japan Surgical Association, v. 68, n. 6, p. 1518-1522, 2007.

Weycker, D.; Akhras, K. S.; Edelsberg, J.; Angus, D. C.; Oster, G. Long-term mortality and medical care charges in patients with severe sepsis. Cfit Care Med, v. 31, p. 2316-2323, 2003.

http://dx.doi.org/10.1097/01.CCM.0000085178.80226.0B 